\title{
Monetary reform under the Sufyanids: the papyrological evidence ${ }^{1}$
}

\author{
Mehdy Shaddel \\ Leiden University, Leiden, The Netherlands \\ mehdyshaddel@gmail.com
}

\begin{abstract}
For the past fifty years, there has been a debate over whether the Umayyad caliph Mu'âwiya introduced a short-lived gold coinage in Syria. After reappraising the literary evidence, this study argues that an enigmatic phrase in a papyrus from this period constitutes evidence for state enforcement of the circulation of a new kind of gold coinage issued under $\mathrm{Mu}$ 'âwiya. A diestudy of the extant specimens of a peculiar imitation of Byzantine gold which has had its crosses effaced, and has been attributed to $\mathrm{Mu}$ 'àwiya on the basis of the testimony of literary sources, confirms them to be the result of a large-scale, albeit ultimately unsuccessful, initiative. This demonstrates that, in addition to the east, there also existed a separate drive towards an expansion of the money supply in Syria-Egypt during the latter half of $\mathrm{Mu}$ 'àwiya's caliphate, a development which testifies to a relatively substantial programme of state-building by the caliph.
\end{abstract}

Keywords: Islamic numismatics, Umayyad caliphate, State formation, Arab-Byzantine coinage, Monetary history

It is well known that the Sasanian empire operated on the basis of the silver standard, with copper playing the role of small change. ${ }^{2}$ The mainstay of the Byzantine monetary system was gold, supplemented by copper as small change ${ }^{3}-$ with the

1 I am much indebted to Sean Anthony (Ohio State University), Robert Hoyland (Institute for the Study of the Ancient World, New York University), Arietta Papaconstantinou (University of Reading), Jelle Bruning (Universiteit Leiden), and especially Luke Treadwell (University of Oxford) for their insightful comments on and constructive critiques of earlier drafts of this paper. My thanks are also due to Michael Bates (American Numismatic Society) for playing my devil's advocate, to Peter Webb (Universiteit Leiden) for sharing his wisdom over a number of issues, and to Hamidreza Rahmani (Florida State University) for helping me with the graphics. The responsibility for all shortcomings and errors, whether of fact or interpretation, remains with me alone.

2 For copper, see Stuart D. Sears, "A monetary history of Iraq and Iran, ca. CE 500 to 750" (unpublished $\mathrm{PhD}$ dissertation, the University of Chicago, 1997), 45-6; Rika Gyselen, Arab-Sasanian Copper Coinage (Vienna: Verlag der Österreichischen Akademie der Wissenschaften, 2000); see, in general, Stefan Heidemann, "The merger of the two currency zones in early Islam: the Byzantine and Sasanian impact on the circulation in former Byzantine Syria and Mesopotamia", Iran 36, 1998, 95-112.

3 In the early seventh century, the emperor Heraclius introduced a new silver coin, the hexagram, to fund his war effort against Sasanian Persia, but this new denomination 
minting of gold being, most of the time, a near-monopoly of the imperial capital, Constantinople. ${ }^{4}$ When the Muslims took over Byzantine Syria and Egypt and the territories of the Sasanian empire, they initially followed the monetary practices of their predecessors: in the east, they simply perpetuated the silver, and the occasional copper, issues of the Sasanian kings of kings Khusraw II (r. 590-628 CE) and Yazdgird III (r. 632-651 CE); in Syria and Egypt, at some point after the conquest of the region, they started minting copper in imitation of Byzantine types, ${ }^{5}$ and gold was imported, in substantial quantities, from Byzantium. ${ }^{6}$ Thus, during the first few decades after the Muslim conquest of the eastern Mediterranean basin, the first Muslim empire was technically divided into two currency zones, each based on a different standard - one gold, and the other silver. Sometime in the first century of Islam, a local gold denomination was also introduced, but when exactly this occurred has long been subject to debate.

In a classic published in 1967, the pioneer of Islamic numismatics, George Miles, gave a comprehensive description of all the known series of the reform and early post-reform gold coinage of the early Islamic empire. ${ }^{7}$ Despite the discovery of several further specimens, this description remains valid, as does the relative chronology Miles established for these emissions based on their iconography and legends. Miles's proposed absolute chronology for these issues, which attributed all of them to the reign of the caliph 'Abd al-Malik ibn Marwān (r. 65-86 AH/685-705 CE) proved less durable, however. Following John Walker, he argued that the testimony of the Syriac and Arabic literary sources to issuance of a gold coinage under Mu'āwiya ibn Abī Sufyān (r. 41$60 \mathrm{AH} / 661-680 \mathrm{CE}$ ) does not hold water in the face of the numismatic evidence, and that the dateless issues would have been issued shortly before those dated 74-77 AH/693-697 CE, on the grounds of continuity and the evidence of Carthaginian comparanda from the Roman exarchate of Africa naturally dating from after the conquest of that region during the reign of 'Abd al-Malik. ${ }^{8}$

In the following decades, Miles's intellectual heir and successor at the American Numismatic Society, Michael Bates, made a more forceful case for this "short chronology", ascribing almost all major monetary initiatives in

seems to have enjoyed little currency in Syria, Palestine, and Egypt; Philip Grierson, Byzantine Coins (Berkeley: University of California Press, 1982), 144. For the hexagram, see ibid., 103-5; for the Byzantine monetary system in general, consult Cécile Morrisson, "Byzantine money: its production and circulation", in Angeliki Laiou (ed.), The Economic History of Byzantium: From the Seventh through the Fifteenth Centuries (Washington: Dumbarton Oaks, 2002), 909-66.

4 Morrisson, "Byzantine money", 911.

5 For a pithy summary of the early Muslim coinage of Syria and Iran, consult Stefan Heidemann, "The evolving representation of the early Islamic empire and its religion on coin imagery", in Angelika Neuwirth, Nicolai Sinai, and Michael Marx (eds), The Qur'ān in Context: Historical and Literary Investigations into the Qur'änic Milieu (Leiden: Brill, 2010), 149-95.

6 There is ample hoard evidence for the circulation of Byzantine gold in Syria in the first Islamic century; see, e.g., William E. Metcalf, "Three seventh-century Byzantine gold hoards", Museum Notes 25, 1980, 87-108; Heidemann, "Merger", 95-7.

7 George C. Miles, "The earliest Arab gold coinage", Museum Notes 13, 1967, 205-29.

8 Miles, "Earliest gold", 228-9. 
Syria - be they reform of the coinage or introduction of new denominations, and whether copper, silver, or gold - to 'Abd al-Malik. ${ }^{9}$ Bates's studies were the high water mark of this short chronology, and thereafter numismatists began to formulate alternative, "longer" chronologies which allowed for some measure of experimentation under the Sufyanids, in particular Mu'āwiya, and during the earlier part of 'Abd al-Malik's reign (the years 65-72 AH/685-691 CE, before the end of the Second Civil War, 60-73 AH/680-692 CE). ${ }^{10}$

The first attempt to establish a longer chronology for the gold coinage actually predated Bates's publications. In an article published in 1972, Cécile Morrisson argued that a particular imitation of the solidi of Heraclius with three imperial figures but no crosses on the obverse and the cross-on-steps on the reverse transformed into a T-shaped object-on-steps is to be attributed to $\mathrm{Mu}$ 'āwiya. She based this argument on the evidence of a fragmentary Syriac text, known as the Maronite Chronicle and composed in the seventh or eighth century, which states that Mu'āwiya issued gold and silver without crosses on them, but that his initiative fell on stony ground, apparently because the predominantly Christian population of Syria would not accept coinage that lacked the image of the cross. ${ }^{11}$ In a later work, she elaborated further on her proposal: ${ }^{12}$ these issues can be divided into two series, the first, which includes the abovementioned imitative issue and which Morrisson aptly dubbed "dechristianized", ${ }^{13}$ bear imperial iconography on the obverse but have had the crosses on the obverse effaced, and the reverse bears a T-shaped object instead of the usual cross-on-steps. ${ }^{14}$ The second series, called the shahäda solidus, similarly bears three imperial figures on the obverse, with the crosses removed, and on the

9 Michael L. Bates, "The 'Arab-Byzantine' bronze coinage of Syria: an innovation by 'Abd al-Malik", in A Colloquium in Memory of George Carpenter Miles (1904-1975) (New York: American Numismatic Society, 1976), 16-27; Bates, "History, geography and numismatics in the first century of Islamic coinage", Revue suisse de numismatique 65, 1986, 231-63; Bates, "The coinage of Syria under the Umayyads, 692-750 A.D.”, in Muhammad 'Adnān Bakhīt and Robert Schick (eds), The Fourth International Conference on the History of Bilād al-Shām during the Umayyad Period: Proceedings of the Third Symposium (Amman: University of Jordan Press, 1989), 195-228.

10 See Luke Treadwell, The Chronology of the Pre-Reform Copper Coinage of Early Islamic Syria (London: Oriental Numismatic Society, 2000); and Tony Goodwin, "The chronology of the Umayyad imperial image coinage: progress over the last 10 years", in Tony Goodwin (ed.), Arab-Byzantine Coins and History: Papers Presented at the $13^{\text {th }}$ Seventh Century Syrian Numismatic Round Table, Held at Corpus Christi College Oxford on $11^{\text {th }}$ and $12^{\text {th }}$ September 2011 (London: n.p., 2012), 89-108, for a history of scholarship.

11 Cécile Morrisson, "Le trésor byzantin de Nikertai", Revue belge de numismatique et de sigillographie 118, 1972, 29-91, at 63.

12 Cécile Morrisson, "Monnayage omeyyade et l'histoire administrative et économique de la Syrie", in Pierre Canivet and Jean-Paul Rey-Coquais (eds), La Syrie de Byzance a l'Islam, VII ${ }^{e}$-VIII ${ }^{e}$ siècles: actes du colloque international Lyon - Maison de l'Orient Méditerranéen Paris - Institut du monde arabe, 11-15 Septembre 1990 (Damascus: Institut français de Damas, 1992), 309-18, at 310-13.

13 Morrisson, "Monnayage omeyyade", 312.

14 It must be noted that the prototype of one subtype of this series, the solidus of Phocas, only has a globus cruciger on the reverse. The number of imperial figures on the obverse of this series also varies between one and three. 
reverse the Latin legends and the cross-bar of the cross-on-steps have been erased and instead the margins are ringed by the Islamic profession of faith, the shahäda. ${ }^{15}$

The debate over the absolute chronology of the gold coinage of Syria took a new turn with the publication in 2002 of an article by Clive Foss, who, building on Morrisson's work, made a strong case for the ascription of the dechristianized solidi - but not the shahāda solidi - to Mu'āwiya. Foss's argument is based on several observations. Above all, he states, Mu'āwiya's regime was much more sophisticated than hitherto imagined, a fact borne out by his initiatives in the east and by the evidence of the Nessana papyri from Palestine. The existence of a rather complex building programme not only requires a much more monetized economy, but also encourages increased monetization and reform. His second piece of evidence is the aforementioned Maronite Chronicle. Third, hoard evidence suggests that these issues were already in circulation not long after $681 \mathrm{CE}$ at the latest, that is, shortly after the death of Mu'āwiya in 680 CE. $^{16}$

Certainly, none of Foss's evidence was new, but his forceful contention with regard to the nature of Mu'āwiya's state marked an important new chapter, and provoked a quick rebuttal by Jeremy Johns. ${ }^{17}$ Johns's sharply formulated arguments against a strong central administration under $\mathrm{Mu}$ 'āwiya, and the subsequent responses by Robert Hoyland, Foss himself, and others, generated a parallel debate amongst historians which obscured the original point of Foss's article - the issuance of gold mintage by Mu'āwiya. ${ }^{18}$ Taking the perspective of a historian and making use of the whole range of available evidence, the present article will attempt to bring the debate back to the original question of Mu'āwiya's minting of gold. In what follows, I shall first deal with literary evidence, focusing mostly on an account in al-Maqrīzī's Shudhūr al-'uqūd fì dhikr al-nuqū $d$ and a neglected passage in an adversus iudaeos composition usually attributed to Anastasius of Sinai. Thereafter, I will turn to an enigmatic phrase in a papyrus fragment which, I contend, is a reference to a new kind of gold coinage issued by Muslims during the reign of $\mathrm{Mu}$ 'äwiya. I will afterwards try, focusing on the accounts of the pledge of allegiance to $\mathrm{Mu}$ 'awwiya, to proffer a new redaction history for the Maronite Chronicle, arguing that the chronicler's

15 Hence the moniker "shahäda solidus" conferred by Luke Treadwell, "Abd al-Malik's coinage reforms: the role of the Damascus mint", Revue numismatique 165, 2009, $357-81$.

16 Clive Foss, “A Syrian coinage of Mu awiya?", Revue numismatique 158, 2002, 353-65.

17 Jeremy Johns, "Archaeology and the early history of Islam: the first seventy years", Journal of the Economic and Social History of the Orient (JESHO) 46, 2003, 411-36.

18 Robert G. Hoyland, "New documentary texts and the early Islamic state", BSOAS 69, 2006, 395-416; Clive Foss, "Mu'āwiya's state", in John Haldon (ed.), Money, Power and Politics in Early Islamic Syria: A Review of Current Debates (Farnham: Ashgate, 2010), 74-96; Clive Foss, "Egypt under Mu'āwiya, part I: Flavius Papas and Upper Egypt", BSOAS 72, 2009, 1-24; "Egypt under Mu'āwiya, part II: Middle Egypt, Fustāt and Alexandria", BSOAS 72, 2009, 259-78; Arietta Papaconstantinou, "Administering the early Islamic state: insights from the papyri", in Haldon (ed.) Money, Power and Politics in Early Islamic Syria, 57-74; see Mehdy Shaddel, The Sufyanids and the Beginnings of the Second Civil War, 660-684 (forthcoming), for a review and reappraisal of the debate. 
reference to Mu'āwiya's minting of crossless coinage at the beginning of the notice for his reign does not necessarily require that it be dated to the first few years of his reign. ${ }^{19}$ I will then argue, following Morrisson, Foss, and others, that these findings constitute strong circumstantial evidence for the identification of the coinage mentioned in our literary sources with a certain series of dechristianized imitations of the Byzantine solidus the crosses on which have been eliminated and which could be dated to the early $680 \mathrm{~s} \mathrm{CE}$ at the latest based on hoard evidence. A die-study of all the extant specimens available to me will reveal that the 19 known specimens have been struck by 19 different obverse and 18 different reverse dies, a large number that bespeaks the huge extent of the caliph's undertaking. Based on these results, I conclude by arguing that the (attempted) introduction of a precious-metal denomination in Syria-Egypt in this period was part of a wider programme of monetary expansion, traces of which we also observe in the eastern part of the empire in the latter half of Mu'āwiya's caliphate, a conclusion that furnishes us with further insights into the workings of the Sufyanid regime.

\section{Literary evidence}

In the introductory discussion to his catalogue of the Arab-Byzantine coins in the British Museum, Walker produced a report from al-Maqrīzī (d. $845 \mathrm{AH} /$ $1442 \mathrm{CE}$ ), according to which Mu'āwiya "struck dinars with a sword-girt figure on them" (wa-daraba mu'àwiya aydan danānīr 'alayhā timthālun mutaqallidan sayfan). ${ }^{20}$ Walker, who rightly saw an obvious reference to the "standing-caliph" gold coins of 'Abd al-Malik in this passage, dismissed the claim as resulting from a confusion, and assumed that this, along with the report of the anonymous Maronite chronicler concerning $\mathrm{Mu}$ 'āwiya's "crossless" gold and silver issues, more likely refers to several bronze issues known to him that fitted the descriptions. ${ }^{21}$ Miles went a step further, dismissing the Arabic account out of hand and glossing over the Syriac report. ${ }^{22}$ For his own part, Bates has questioned the veracity of the latter's testimony on the grounds of its complicated redaction history and its reference to a silver issue,

19 The chronology of the base-metal coinage of Syria and Egypt falls well beyond the scope of the present study. See Tony Goodwin, "The Egyptian Arab-Byzantine coinage", in Andrew Oddy, Ingrid Schulze, and Wolfgang Schulze (eds), Coinage and History in the Seventh Century Near East 4: Proceedings of the 14th Seventh Century Syrian Numismatic Round Table Held at the Hive, Worcester, on 28th and 29th September 2013 (London: Archetype, 2014), 205-16; and Goodwin, "Chronology of the Umayyad imperial image coinage", for the status quaestionis.

20 al-Maqrīzī, Shudhūr al-'uqūd fì dhikr al-nuqūd (Constantinople: Mațba at al-jawā'ib, 1298/1880), 5; quoted in John Walker, A Catalogue of the Muhammadan Coins in the British Museum, vol. ii: A Catalogue of the Arab-Byzantine and post-Reform Umaiyad Coins (London: Trustees of the British Museum, 1956), xxxi. Walker, who is reliant on another, facsimile edition, gives the text as 'alayhā timthāluhu, indicating that the figure on the obverse was a depiction of the caliph himself.

21 Walker, Catalogue, xxv, xxxi-xxxii.

22 Miles, "Earliest gold", 215-16. 
and has postulated a confusion between $\mathrm{Mu}$ 'āwiya and 'Abd al-Malik, who issued both gold and silver in Syria, here. ${ }^{23}$

But Bates's objection that "the only silver coinage the Syrians would have known would have been the Iranian drachms" which had no crosses on them to be removed by $\mathrm{Mu}^{\text {'âwiya }}{ }^{24}$ also applies to his favoured candidate, 'Abd al-Malik, whose Syrian silver issues were based on Sasanian prototypes, which, of course, did not have the image of the cross on them. With respect to his observation concerning the similarity in the treatment of the prototypes in this series and the "shahāda solidus",25 it must be pointed out that there are stylistic differences in the depiction of the imperial figures on the obverses of the two series, as noted already by Miles, ${ }^{26}$ and that, to the best of my knowledge, none of the extant specimens of the former with three imperial figures on the obverse shares an obverse die with the latter group. Now, had the latter series followed on the heels of the former as a natural development, as Bates would have it, one would have expected the obverses to have looked exactly the same, and very likely also sharing some dies. What is more, the issues of the early Islamic mint of North Africa, in Carthage, treat their prototypes in a similar fashion, resulting in a T-shaped object-on-steps, instead of the usual cross-on-steps, on the reverse. These issues obviously date to after the conquest of the region by Muslims in $79 \mathrm{AH} / 698 \mathrm{CE},{ }^{27}$ and should have been considered contemporaneous with the dechristianized issues of Syria if we were to go by Bates's continuity argument, ${ }^{28}$ but Syria had already transitioned to standingcaliph gold in the year $74 \mathrm{AH}$. Hence, the argument from continuity does not sound very strong either.

The existence of stylistic differences on the obverses of the dechristianized series and the shahāda solidus is also why Morrisson's attribution of the latter to $\mathrm{Mu}$ 'àwiya is to be rejected. Foss, too, parts ways with her here, ${ }^{29}$ presumably on the grounds of the stylistic similarity of the reverse of this series to the standing-caliph issues of 'Abd al-Malik, an argument first advanced by Bates. ${ }^{30}$ Put simply, the obverse of the shahäda solidus exhibits stylistic differences with the dechristianized issues which, contra Morrisson and Bates, make the likelihood of the two of them having been issued in quick succession little, whereas its reverse exhibits similarities to the standing-caliph series which,

23 Michael Bates, "Commentaire sur l'étude de Cécile Morrisson", in Canivet and Rey-Coquais (eds), La Syrie de Byzance a l'Islam, 319-21. This possibility is also entertained by Heidemann, "Evolving representation", 161.

24 Bates, "Commentaire", 319.

25 Bates, "History, geography and numismatics", 239.

26 Miles, "Earliest gold", 210. Also adumbrated by Bates himself, "History, geography and numismatics", 243: "the gold coins ... have three figures on the obverse in what seems to be Arab dress (certainly not Byzantine imperial costume)". Here (ibid., 239, n. 10) Bates arbitrarily dissociates those dechristianized issues with one or two imperial figures on the obverse from those with three figures on the obverse.

27 For the Muslim conquest of Carthage, see Walter E. Kaegi, Muslim Expansion and Byzantine Collapse in North Africa (Cambridge: Cambridge University Press, 2010), especially $247-65$.

28 Cf. Miles, "Earliest gold", 229.

29 Foss, "Syrian coinage", 363.

30 Bates, "Coinage of Syria", 200-01. 
contra Morrisson, make it more likely for the latter to have immediately followed the shahāda solidus.

Overall, there seems to be some merit to the literary evidence, as al-Maqrīzì's information on early Islamic coinage is otherwise generally accurate, and the Maronite Chronicle seems to be reliant on eye-witness accounts for many of its reports. I therefore believe that Walker was right in asserting that al-Maqrīzì's report is confused, but it is more likely that the confusion only involves the coin's iconography, and not the issuing authority. This seems all the more likely in the light of the fact that, later in the text, al-Maqrīin does not mention the standing-caliph issues in the context of 'Abd al-Malik's reforms, despite showing awareness of the fact that his early reform emissions included "human depiction" (fihi șüratun). ${ }^{31}$ It is also possible that, as Bates states, the Syriac chronicler's reference to "silver and gold" is likewise a confusion, but I would not go so far as to dismiss the whole account as unreliable. It is, after all, possible that "gold and silver" are being used in the general sense of "money" here; it is not impossible either that the chronicler, when stating that $\mathrm{Mu}$ 'âwiya's new coinage "was not accepted, because it had no cross on it", 32 only had gold in mind. ${ }^{33}$ I believe Bates is right in asserting that the text has a tortuous redaction history, ${ }^{34}$ but there is universal consensus among historians on the historical value, despite problems of chronology, ${ }^{35}$ of what precious little this fragmentary text has to offer, and it is equally possible to postulate a confusion between copper and silver here.

It is also noteworthy that both of these two sources mention or allude to the initiative's failure. Unlike the Maronite chronicler, al-Maqrīzī does not say anything about its failure explicitly, but he produces an account to that effect, according to which, after the introduction of the new coinage, "an old soldier" (shaykhun min al-jund), having found it to be of a "despicable" form (rad $\vec{\imath})$, ridicules $\mathrm{Mu}$ 'āwiya and his new issues by saying, "Mu'āwiya, we have found your mintage to be the worst ever!" (yā mu'āwiya innā wajadnā darbaka sharr darbin!) To which Mu'āwiya replies by promising to cut off his stipend ( $a t \bar{a}^{\prime}$ ) and clothe him in velvet attire $(q a t \bar{l} f a)^{36}$ - a thinly disguised death threat. $^{37}$ This account is obviously fabulous, and the exchange between the

31 al-Maqrīzī, Shudhūr al-'uqūd, 6.

32 Andrew Palmer, with a contribution by S.P. Brock and assistance from Robert G. Hoyland, The Seventh Century in the West-Syrian Chronicles (Liverpool: Liverpool University Press, 1993), 32.

33 Foss, "Syrian coinage", 362, takes this to be a reference to the silver issued in the east.

34 Cf. Robert G. Hoyland, Seeing Islam as Others Saw It: A Survey and Evaluation of Christian, Jewish and Zoroastrian Writings on Early Islam (Princeton: Darwin, 1997), 139; Michael Philip Penn, When Christians First Met Muslims: A Sourcebook of Earliest Syriac Writings on Islam (Oakland, CA: University of California Press, 2015), 56-7; see also further infra.

35 Cf. Andrew Marsham, "The architecture of allegiance in early Islamic late antiquity: the accession of Mu'āwiya in Jerusalem, ca. 661 CE”, in Alexander Beihammer, Stavroula Constantinou, and Maria Parani (eds), Court Ceremonies and Rituals of Power in Byzantium and the Medieval Mediterranean: Comparative Perspectives (Leiden: Brill, 2013), 87-112.

36 al-Maqrīzī, Shudhūr al-'uqūd, 5.

37 Red velvet (qatîfa hamrä') was apparently commonly used to cover the bodies of the dead, as evidenced both by literary sources and a papyrus fragment from $c$. the 
old soldier and $\mathrm{Mu}$ 'āwiya might just be a literary form, but there is certainly nothing here to suggest that the report's presumption of opposition to the reform is somehow tendentious. ${ }^{38}$

Further evidence for the introduction of a peculiarly non-Roman gold coinage before the close of the Second Civil War comes from an unlikely source brought to light by the Byzantinist Walter Kaegi, but unfortunately neglected by numismatists. This is an anti-Jewish tractate known as Adversus Iudaeos Disputatio, ascribed to the seventh-century figure Anastasius Sinaita (fl. second half of the seventh century $\mathrm{CE}$ ). The ascription of the whole text to Anastasius has occasionally been questioned, but Kaegi has put forward compelling arguments for the authenticity, or at least antiquity, of a particular passage concerning the gold coinage of the Byzantine empire. ${ }^{39}$

That the Christian Roman empire held domination over large parts of the known world before the rise of Islam, whereas the Jews had been a subject nation, ruled by pagan potentates since the days of yore, had been a stock item in the repertoire of Christian anti-Jewish polemic of late antiquity. Unfortunately for Christians, though, a string of misfortunes in the seventh century that began with a devastating Sasanian onslaught against the Byzantine empire and culminated in the rise of Islam and its subjugation of substantial parts of East Roman territories, along with their Christian populations, turned the tables against them, and consequently justification of the present status of Near Eastern Christians became a recurrent theme in Christian apologetics of this period. ${ }^{40}$ It is in the context of one such apologetic exposition that Anastasius brings up the subject of the gold coinage of the Byzantine empire:

no Christian emperor has ever suffered death at the hands of barbarians, even though so many barbarian nations fought the empire. They not only failed to eliminate the emperor, but failed to eliminate his picture with the cross from the nomisma, even though some tyrants attempted to do so. Do not consider this a simple and mean thing, that the embattled faith is standing and not fading. For unless God had chosen and loved our nation, He would not have protected it from the wolflike nations. ${ }^{41}$

Anastasius then elaborates further on this argument:

second/eighth century containing instruction on proper burial and funerary practices; Alia Hanafi, "Two new Arabic editions: a land survey from Ihnās and hadìths concerning funerary practice", in Alexander T. Schubert and Petra M. Sijpesteijn (eds), Documents and the History of the Early Islamic World (Leiden: Brill, 2015), 261-90, at 275-7, P. ACPSI 126, side A, lines 1 and 2, and the commentary thereto (I am grateful to Joe Bradford for first suggesting to me a connection with death in Mu'āwiya's words).

38 My thanks to Luke Treadwell for helping with the interpretation of this passage.

39 Walter E. Kaegi, Byzantium and the Early Islamic Conquests (Cambridge: Cambridge University Press, 1992), 221-7.

40 See David M. Olster, Roman Defeat, Christian Response, and the Literary Construction of the Jew (Philadelphia: University of Pennsylvania Press, 1994), for more.

41 The translation is taken from Kaegi, Byzantium, 223. This passage can also be found in the Dialogue between Papiscus and Philo and Quaestiones ad Antiochum Ducem (see Kaegi, Byzantium, 223, for the specifics and discussion). 
How is it that no one was strong enough to deny or to remove the seal of gold from us? How many kings of the gentiles, Persians, Arabs, tried this and did not prevail at all? So that God could show that, even if we Christians are persecuted, we reign over all. For the gold sign of our empire is a sign of Christ Himself. Tell me then, if it is not a sign that the faith and the empire of the Christians is eternal, invincible, and indelible, why have you lapsed from it - you who all hate and blaspheme the cross of Christ?

Why are you not able to abandon the cross of gold, but eagerly receive it, and yet if you see gold without the cross, you curse it and turn away?... Why do you desire what you make war against, and [why do you] eagerly receive, being [thereby] unexpectedly conquered, what you curse? And if you have sense and understanding, this sign would suffice for all of you, to show and to persuade you that the faith and the cross of Christ will reign forever through the ages. ${ }^{42}$

Sadly, we do not know enough about Anastasius's life, or the actual authorship of these two passages, to be able to assign a date to them, ${ }^{43}$ but the reference to an attempt by the new masters of the east Mediterranean world to remove the "emperor's picture with the cross" from the coinage has led Kaegi and Hoyland to treat this as a corroboration of the Maronite chronicler's report on the removal of the cross from the coinage. ${ }^{44}$

Anastasius's assertion that the image of the emperor was also effaced from the coinage, which only occurs in one of the two passages cited above, might be taken as an allusion to 'Abd al-Malik's standing-caliph issues, ${ }^{45}$ but the fact remains that the standing-caliph issues were then replaced by aniconic coins. It would obviously be pointless to boast of the failure of an attempt to remove Christian iconography from the coinage at a time when such coins were completely replaced by new issues that, in the words of a late-seventh-century apocalyptist writing under the name of archbishop Athanasius of Alexandria (c. 295-373 CE), had the "name of a beast" (that is, Muhammad ${ }^{46}$ ) written on them. The contrast between the triumphalist tone of

42 Kaegi, Byzantium, 224.

43 For the Anastasian corpus, check John Haldon, "The works of Anastasius of Sinai: a key source for the history of seventh-century East Mediterranean society and belief', in Averil Cameron and Lawrence I. Conrad (eds), The Byzantine and Early Islamic Near East, vol. i: Problems in the Literary Source Material (Princeton: Darwin, 1992), 107-47; and now Karl-Heinz Uthemann, Anastasios Sinaites: Byzantinisches Christentum in den ersten Jahrzenten unter arabischer Herrschaft (Berlin: Walter de Gruyter, 2015), especially vol. 2, 703-11, on the crossless gold.

44 Kaegi, Byzantium, 226-7 (though with some circumspection); Robert G. Hoyland, "Numismatics and the history of early Islamic Syria", in Andrew Oddy (ed.), Coinage and History in the Seventh Century Near East 2: Proceedings of the 12 $2^{\text {th }}$ Seventh Century Syrian Numismatic Round Table Held at Gonville and Caius College, Cambridge on 4th and 5th April 2009 (London: Archetype, 2010), 81-93, at 90; Hoyland, Seeing Islam, 84-5, and n. 98 thereto.

45 A possibility that Kaegi, Byzantium, 226-7, seems willing to entertain.

46 Francisco Javier Martinez, "Eastern Christian apocalyptic in the early Muslim period: pseudo-Methodius and pseudo-Athanasius" (unpublished $\mathrm{PhD}$ dissertation, the Catholic University of America, 1985), 264. 
Anastasius when relating the invincibility of the symbols of Christianity and pseudo-Athanasius's defeatism of a few years later cannot possibly be starker:

that nation [viz., the Ishmaelites] will destroy the gold on which there is the image of the cross of our Lord, our God, in order to make all the countries under its rule mint their own gold with the name of a beast written on it, the number of whose name is six hundred and sixty six. ${ }^{47}$

Judging by the reference to the name of Muhammad on the coinage and the brooding over the removal of the cross, the oldest stratum in pseudoAthanasius was evidently written shortly after 'Abd al-Malik's reforms of the 70s $\mathrm{AH}$, when the memory of the older coinage that bore the image of the cross on the reverse was still fresh in the minds of the Christians living under Muslim rule. There are two further internal references elsewhere in the text that confirm this dating: first, there is also mention of a population census and a cadastral survey, which may be taken to refer to 'Abd al-Malik's surveys of $c$. $72 \mathrm{AH} ;{ }^{48}$ second, the text then goes on to state that, shortly before the end of Muslim domination, they will begin to "chase the strangers in the cities and villages" and "throw them into prisons". ${ }^{49}$ In an excellent and exhaustive study of the censuses and surveys conducted under the Umayyads, Wadād al-Qāḍ̄ has shown that there must have been a population census in Egypt in c. $74 \mathrm{AH},{ }^{50}$ followed by a census of the "strangers" (presumably meaning fugitives), reported by several Syriac sources, on the orders, probably, of the governor of the coastal region of Syria in 78 AH. $^{51} \mathrm{We}$ do not know anything about the extent of this latter undertaking, and there is no information about a similar census of fugitives elsewhere at this time, but it is conceivable that such measures proved necessary all over the empire after the initial census(es) of $c .72 \mathrm{AH}$. We can, therefore, safely assume that by the "chasing of the strangers" a census of the fugitives is intended, ${ }^{52}$ and as such the likely date of the first redaction of our apocalypse should be placed at immediately after the census of fugitives in $78 \mathrm{AH}-$ as this was supposed to be the last act of the Muslim state before its prophesied imminent downfall. ${ }^{53}$

47 Martinez, "Eastern Christian apocalyptic", 529-30 (also quoted by Kaegi). Six hundred and sixty six is the alphabetic numerical value of Muhammad's name in Coptic; ibid., 264.

48 For some reason, Hoyland, Seeing Islam, 284-5 (apparently following Martinez, "Eastern Christian apocalyptic", 575, n. 16), takes the conclusion of 'Abd al-Malik's coinage reform in $77 \mathrm{AH}$ as the terminus post quem for this passage, and then puts the date of composition after the next census in $96 \mathrm{AH}$. However, there is no reason why the author could not have had the previous census of $72 \mathrm{AH}$ in mind here. On the surveys themselves, see Wadād al-Qādīi, "Population census and land surveys under the Umayyads (41-132/661-750)", Der Islam 83, 2008, 341-416, at 364-86.

49 Martinez, "Eastern Christian apocalyptic", 530-31.

50 al-Qāḍ̄i, "Population census", 381-6.

51 al-Qādị, "Population census", 379-81.

52 As noted by Martinez, "Eastern Christian apocalyptic", 577, n. 21.

53 Note also that there is a reference in the text to the Muslim leader living in Damascus (Martinez, "Eastern Christian apocalyptic", 528), from which Hoyland, Seeing Islam, 
Anastasius Sinaita's text, then, must date to before the period of 'Abd al-Malik's reforms. Furthermore, the focus of the second part of Anastasius's argumentation is on the cross alone, which invites one to consider the possibility that the earlier mention of the removal of "the emperor's picture with the cross" is mere rhetoric: not only were the "barbarians" unable to harm the person of the emperor, they could hardly even lay their hands on his image. ${ }^{54}$ Anastasius and our Maronite author are, therefore, referring to a similar, if not the same, initiative, one that involved the effacement of the cross from the coinage, but scarcely anything more, and was met with popular resistance.

In addition to these, Bates has drawn attention to a passage in the Chronographia of the Byzantine monk and historian Theophanes the Confessor on the unusual appearance of the coins sent as tribute to Byzantium by 'Abd al-Malik shortly after the close of the Second Civil War, based on which he argues that the reform of the coinage and the introduction of a gold denomination must have begun under 'Abd al-Malik. ${ }^{55}$ Theophanes's report might be construed as conflicting with the Maronite chronicler's, but a closer inspection of the two texts' wording would reveal this apparent conflict to be illusory. According to Theophanes, in AM 6183 (71-72 AH/690-691 CE),

Justinian foolishly broke the peace with Abimelech [i.e. 'Abd al-Malik]; for he strove in his folly to move the population of the island of Cyprus and refused to accept the minted coin that had been sent by Abimelech

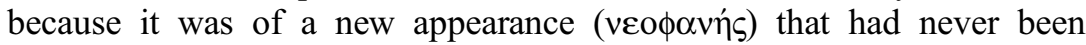
made before. When Abimelech had been informed of this, he diabolically feigned to be begging that peace should not be broken and that Justinian should accept his currency, seeing that the Arabs could not suffer the

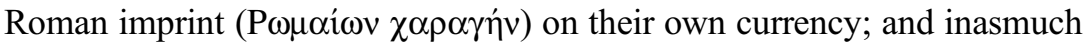
as the gold was paid by weight, the Romans did not suffer any loss from

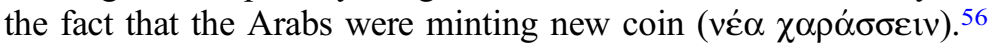

283 (again following Martinez, "Eastern Christian apocalyptic", 264 and 575, n. 12), has inferred a terminus ante quem of $126 \mathrm{AH}$ for the composition, prior to the accession of Marwān II. I must, however, point out that no caliph after Yazīd II (r. 101-105 AH) ever resided in Damascus (save for Yazīd III, during his six-month-long caliphate in $126 \mathrm{AH}$ ), which brings this terminus ante quem two decades earlier to $105 \mathrm{AH}$ (also noted by Martinez, "Eastern Christian apocalyptic", 279, n. 34, but without further consideration). Hishām (r. 105-124 AH), who lived out the days of his long reign in Rușāfat Hishām, and al-Walīd II (r. 124-126), who was perennially attached to the Jordanian desert since adulthood, seem to have generally avoided urban areas, possibly because of the plague, which was a frequent visitor at the time; Antoine Borrut, Entre mémoire et pouvoir: l'espace syrien sous les derniers Omeyyades et les premiers Abbassides (v. 72-193/ 692-809) (Leiden: Brill, 2011), 423-4, 427-8.

54 One would also do well to remember here that Decius (d. $251 \mathrm{CE}$ ), Valerian (d. c. $260 \mathrm{CE}$ ), Julian (d. $363 \mathrm{CE}$ ), and Valens (d. $378 \mathrm{CE}$ ) were all killed at the hands of "barbarians".

55 Bates, "History, geography and numismatics", 245-50.

56 Text: Theophanis chronographia, vol. 1, ed. Carolus de Boor (Leipzig: B.G. Teubner, 1883), 365; translation adapted from Cyril Mango and Roger Scott, with assistance 
The account is unambiguous and makes it clear that the new currency issued by 'Abd al-Malik was not an imitative issue with minor variations on its Byzantine prototype, but a new mintage of a wholly different look that had "never been made before". These new emissions did not have the "Roman imprint" on them, a description that scarcely fits with the crossless issues that otherwise faithfully imitate their Byzantine originals, but perfectly matches the shahäda solidus of 'Abd al-Malik. One would also imagine that if these issues merely had deformed crosses on them, Theophanes's source, just like Anastasius and the Maronite chronicler, would have explicitly pointed this out rather than making just a general observation about their alien imprint. On the other hand, the Maronite Chronicle's reference to the absence of the cross from Mu'âwiya's coinage, with apparently no other noteworthy peculiarity, and Anastasius's explicit statement concerning the removal of the cross from the Byzantine solidus, but without any other iconographic change, match the appearance of the crossless issues - which, to quote Morrisson, are "dechristianized" but not yet "Islamized". ${ }^{57}$ While Bates is certainly right to ascribe the undated series of the shahāda solidus to 'Abd al-Malik on the basis of this report, the text does not warrant the attribution of the crossless, dechristianized series to him as well ${ }^{58}$ and, accordingly, we should side with Morrisson and Foss to assign this dechristianized type to Mu āwiya. To put it simply, Theophanes's account of the early 70s AH describes the shahāda solidus of 'Abd al-Malik, whilst the Maronite's report on the reign of Mu'āwiya describes dechristianized issues, and as such there is no conflict between the two, or any problem with assigning the latter issues to the Sufyanid period.

In sum, each of the reports in our literary sources quoted above is in some respect problematic, yet it is very remarkable that virtually all of them appear to converge on two points: that at some point in the seventh century a new coinage, further attributed by some to Mu'āwiya, was introduced which lacked the image of the cross; and that the measure was met with popular disapproval and ultimately failed.

from Geoffrey Greatrex, The Chronicle of Theophanes Confessor: Byzantine and Near Eastern History, $A D$ 284-813 (Oxford: Oxford University Press, 1997), 509-10.

57 Morrisson, "Monnayage omeyyade", 312. It might be argued that these T-shaped objects are, in fact, a T-shaped cross, as suggested by Stefan Heidemann, "The standing caliphtype - the object on the reverse", in Andrew Oddy (ed.), Coinage and History in the Seventh Century Near East 2: Proceedings of the 12th Seventh Century Syrian Numismatic Round Table Held at Gonville and Caius College, Cambridge on 4th and 5th April 2009 (London: Archetype, 2010), 23-34, at 27, n. 7. But the fact remains that the issues' deviation from the standard iconography of the Byzantine solidus is too marked, and their date, based on hoard evidence, too close to the date given by literary sources for the "crossless" issues, to allow for such an understanding. More importantly, the crosses on the obverse of the originals have been totally removed in these imitations.

58 Bates, however, does not base himself on this passage to attribute the dechristianized series to 'Abd al-Malik. 


\section{Qậă’ al-mu'minīn revisited}

In 2007, Yūsuf Rāgib published two fragmentary papyrus sheets, P. Louvre inv. J. David-Weill 20 and P. Vindob. A 1119, both datable to the Sufyanid period and from Egypt, containing the cryptic phrases sanat qad̄a' al-mu'minin and

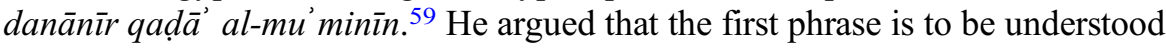
as "l'année de la juridiction des croyants", but failed to offer any comments on the second phrase, confining himself to translating it as "dinars de la juridiction des croyants". 60

These fragments quickly generated much interest and debate. Jelle Bruning proposed a different reading for sanat qad̄a' al-mu' minin, suggesting that the phrase, which he took to be a "validity clause", is to be read as sunnat qad $\vec{a}$ al-mu'minin, "in accordance with the normative procedure of the believers". ${ }^{61}$ This reading's appeal was in the fact that it solved the difficulty with the second phrase, danānīr qad̄a al-mu'minin, at least at the semantic level, or else we would have to entertain the idea of "a certain type of coin" being intended here - as Bruning dismissively notes with regard to Rāgib's translation. ${ }^{62}$

In a recent article, I attempted to show that there are insuperable semantic and syntactical problems with Bruning's reading, and instead suggested that the first phrase probably means "the year according to the reckoning of the believers". 63 Nevertheless, I, too, failed to offer even a tentative interpretation for the second phrase, and confined myself to joining Bruning in his dismissal of Rāgib's translation. ${ }^{64}$

Before moving forward, one issue needs to be settled: Bruning, in the same article, also edited a new fragment, P. Louvre inv. E 7106, that recorded the date of its composition as sanat arba' wa-arba'in sanatin ("the year 44"). He concluded that the second sana (which he reads as sunna) in the phrase was certainly shorthand for sanat qaḍa al-mu'minin (read by him as sunnat qad $\vec{a}^{\prime}$ al-mu'minin). I, followed by Mathieu Tillier and Naïm Vanthieghem, took him up on this idea and further elaborated on it. ${ }^{65}$ However, I later came across a funerary inscription from Najrān, Saudi Arabia, dated to sanat sitt 'ashra sanatin wa-khams mi" a sanatin ("the year 516"), which similarly employs the word sana both before and after the date. ${ }^{66}$ This epitaph is of course very late, but the

59 Yūsuf Rāgib, "Une ère inconnue d'Égypte musulmane: l'ère de la juridiction des croyants", Annales islamologiques 41, 2007, 187-207.

60 Rāgib, "Une ère inconnue", 202-4.

61 J. Bruning, "A legal sunna in dhikr haqqs from Sufyanid Egypt", Islamic Law and Society 22, 2015, 352-74.

62 Bruning, "A legal sunna", 370.

63 Mehdy Shaddel, "'The year according to the reckoning of the believers': Papyrus Louvre inv. J. David-Weill 20 and the origins of the hijrī era", Der Islam 95, 2018, 291-311.

64 Shaddel, "The year", 301.

65 Mathieu Tillier and Naïm Vanthieghem, "Recording debts in Sufyānid Fusțāt: a reexamination of the procedures and calendar in use in the first/seventh century", in John Tolan (ed.), Geneses: A Comparative Study of the Historiographies of the Rise of Christianity, Rabbinic Judaism, and Islam (London: Routledge, 2019), 148-88.

66 Discovered by the joint Saudi-Japanese-French archaeological mission to Najrān, but as yet unpublished. A photograph of the inscription can be found at the following address: https://www.almrsal.com/post/666998 (last accessed 13 June, 2021). 
similarity in texture is striking. Sometime later, another inscription from Egypt and dated to sanat thamān wa-m[i'a] sanatin ("the year 108") was brought to my attention. ${ }^{67}$ Both this formula and the phrase sanat qaḍa' al-mu' minīn have since surfaced in several other papyri from Egypt. ${ }^{68}$ We thus now have three fragments containing the phrase sanat qad̄ä al-mu'minin, all of which date to Egypt of the 40s AH and appear to belong to state registers. ${ }^{69}$ But numerous papyrus fragments and inscriptions datable to as early as $20 \mathrm{AH}$ and as late as the sixth century AH, and from Egypt, Palestine, and Arabia, that use the formula sanat kadha wa-kadha sanatin are now known, and many more are likely to come to light in the future. It is thus conceivable that the two formulae are unrelated, and it is preferable to regard the formula sanat kadha wa-kadha sanatin as a circumlocutory, though fairly idiomatic, way of giving the date, which would literally translate "the year which is such-and-such years". ${ }^{70}$ In any event, the extrapolation of the locution sanat qad̄a al-mu'minin wherever the word sana shows up at the end of a sentence in a papyrus fragment is unwarranted, and it is advisable to focus on the phrase sanat qad $\vec{a}^{\prime}$ al-mu' minin alone in attempting to offer an interpretation for it, and consider the other formula inconsequential for the present discussion.

Tillier and Vanthieghem have recently brought to light further fragments containing the phrase sanat qad $\vec{a}^{\prime}$ al-mu minin, and have advanced several proposals for the meaning of the phrase. Having noticed that all these documents are acknowledgements of debt, they perceptively argue that the phrase qad $\vec{a}^{\prime}$ al-mu' minin, whatever its meaning, must have something to do with fulfilment of debt. Building on this observation, they put forward the possibility that the term qad $\vec{a}$ ' here is to be understood in the sense of "fulfilment of debt", a sense in which it is already attested in some of the oldest Arabic papyri, ${ }^{71}$

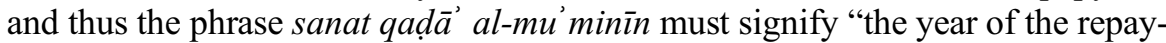
ment of the believers". Such precise specification of the dating system was required because otherwise, they argue, the resultant ambiguity would have rendered the legality of the contract questionable..$^{72}$

This argument is very convincing and I should like to heartily embrace this much more nuanced interpretation, but I would argue that the phrase is not to be understood as a formal name or appellation for a calendrical system, and is rather used in the generic sense of "a year, a chronological system, used by the believers for repayment purposes". This usage is not without similarities to, say, the French use of the phrase "notre ère", or even the English phrase "common era", for the chronology that has its ostensible epoch at the birth of Jesus Christ: unlike such descriptors as "anno domini", it does not tell us

67 Gaston Wiet, Catalogue général du musée de l'art islamique du Caire: inscriptions historiques sur pierre (Cairo: Institut français d'archéologie orientale, 1971), 1-2 and plate 1 (I am grateful to Eugenio Garosi for drawing my attention to this inscription).

68 See Tillier and Vanthieghem, "Recording debt", 148-9, for a list of papyri that employ the formula.

69 As noted in Tillier and Vanthieghem, "Recording debt", 148-9.

70 I am much indebted to François de Blois for helping me to parse out this phrase.

71 E.g. P. Vindob. inv. A. P. 519 (dated 20 AH, the oldest known Arabic papyrus), edited in Tillier and Vanthieghem, "Recording debt", 168-72.

72 Tillier and Vanthieghem, "Recording debt", 157-9. 
much about the epoch of the era, or about how "Western" society conceives of its reckoning system, but is rather a general way of referring to it - "it is our era", or "the era commonly used amongst us". Hence, little significance ought to be attached to the phrase sanat qad $\vec{a}^{\prime}$ al-mu'minin, as, not being an appellation used by the early believers ${ }^{73}$ for their reckoning system, its potential to shed light on the meaning and significance they attached to their calendar is very limited. ${ }^{74}$

\section{Dinars of the believers}

With respect to the phrase danānīr qaḍa al-mu'minīn, Tillier and Vanthieghem suggest, in a more serious vein than Bruning and I, that it may indeed have been some kind of money used under the "rule of the believers", a coinage that might have employed the dating system referred to in the same and other papyri as sanat qad $\bar{a}^{\prime}$ al-mu' minīn on its reverse - though not without immediately noting its unlikelihood in the light of the numismatic evidence. ${ }^{75}$ I should like, however, to submit that the phrase danānīr qad $\vec{a}^{\prime}$ al-mu' minin is to be likewise understood as "dinars of the repayment of the believers" or, more straightforwardly, the "dinars used by the believers in their transactions". To invoke a parallel from the modern world, this is similar to our use of the words "US dollar" when referring to the greenback, so as to demarcate it from other currencies named "dollar". And, just as there is a difference between the US and, say, Australian dollars, there certainly must have been a difference between these "dinars of the believers" and other dinars. So, what kind of dinars were they, and how did they differ from others?

One may argue that "dinars of the believers" were mintages issued per a new weight standard introduced or sanctioned by the believers. ${ }^{76}$ However, the document containing this phrase, P. Vindob. A 1119 , is dated to $57 \mathrm{AH}$, that is, to the final years of Mu'âwiya's reign, and, throughout the first century $\mathrm{AH}$, the Alexandrian gold standard introduced in the previous century under Byzantine rule was the weight standard predominantly used in Egypt. Datable references to this standard gradually disappear from the papyri by the $50 \mathrm{~s} \mathrm{AH}$, but there is circumstantial evidence for its continued use until the second century AH, and, at any rate, Egypt's Muslim conquerors did not introduce a new weight

73 For "believer" as a marker of self-identity in early Islam, check Fred M. Donner, "From believers to Muslims: confessional self-identity in the early Islamic community", Al-Abhath 50-51, 2002-03, 9-53; for its manifestation in the epigraphic record, consult Ilkka Lindstedt, "Who is in, who is out? Early Muslim identity through epigraphy and theory", Jerusalem Studies in Arabic and Islam 46, 2019, 147-246.

74 Pace Shaddel, "The year", and as noted by Tillier and Vanthieghem, "Recording debt", 159 , who, however, then opt for another, more consequential interpretation.

75 Tillier and Vanthieghem, "Recording debt", 160. They then opt for "dinars of the decree of the believers" for its translation (and the "year of the decree of the believers" for sanat qad $\vec{a}^{\prime}$ al-mu' minin), noting that "dinars of the reimbursement of the believers" does not make much sense (ibid., 180). But I believe the same could be said of "dinars of the decree of the believers".

76 I owe this suggestion to Michael Bates. 
standard of their own until the early second century AH. ${ }^{77}$ Moreover, references to a weight standard in the papyri tend to be quite clear (such as a request by the governor Qurra ibn Sharīk for the dinars to be 'alà wazn bayt al-māl, "according to the weight of the treasury") ${ }^{78}$ whereas P. Vindob. 1119 is the only example known to me of a qualified reference in the papyri to a currency denomination without precisely setting out what is being qualified. ${ }^{79}$ One should not also lose sight of the fact that this is a legal document, where equivocation and vagueness could render the transaction null and void. If a weight standard were involved here, it would have been explicitly mentioned; as a matter of fact, the manner in which these "dinars of the believers" are referenced in the papyrus suggests that they were readily distinguishable from their appearance. I therefore take this to be a generic reference to a new type of coinage, a "dinar used by the believers for their business purposes" - obviously a kind of dinar not simply, or at all, of a different weight and value - rather than a vague invocation of a hypothetical, clearly defined weight standard.

The laconic nature of the reference to these "dinars of the believers" in our papyrus indicates that the difference in style and iconography of these dinars would have been readily apparent, with no need for further specification as to their characteristics, and therefore they should be identified with a new issue, rather than the Byzantine solidus, or at least an imitation thereof. That these dinars must have been different from their Byzantine prototypes is also evident from another fact. Tillier and Vanthieghem have unquestionably demonstrated that these debt acknowledgements are in fact official registers that were kept by local authorities. ${ }^{80}$ That is to say, the requirement that the debt be paid in these new coins was stipulated by the officials in charge of overseeing the agreements, which indicates that the fledgling regime of the believers felt a need to enforce the circulation and use of the new currency. Had these issues readily gained general acceptance, there would have been no need for the stipulation that the debt should be paid in the new dinar. This constitutes evidence, albeit tangential, for the report in our literary sources on the opposition to Mu'āwiya's new coinage.

The Muslim state does not seem to have shown interest in driving Roman gold out of circulation at this time, certainly because of the limited means and

77 Jelle Bruning, The Rise of a Capital: al-Fustatt and Its Hinterland, 18/639-132/750 (Leiden: Brill, 2018), 69-73. 'Abd al-Malik's wholly epigraphic coinage, first introduced in $77 \mathrm{AH}$, was struck to a somewhat lower weight standard of 4.25 grammes (Treadwell, “'Abd al-Malik's coinage reforms", 366), but as stated above references to it do not crop up in the papyri until the next century.

78 Adolf Grohmann, with a contribution by Carl Schmidt, Arabic Papyri in the Egyptian Library (Cairo: Egyptian Library Press, 1938), vol. iii, no. 149 (pp. 15-18), at 17; cited by Michael L. Bates, "Coins and money in the Arabic papyri", in Yusūf Rāgib (ed.), Documents de l'islam médiéval: nouvelles perspectives de recherché: actes de la table ronde, Paris, 3-5 mars 1988 (Cairo: Institut français d'archéologie orientale, 1991), 43-64, at 46.

79 It must be added that even if this phrase were a reference to a new weight standard, it would still constitute evidence for some kind of "reform" of, or "innovation" into, the coinage, for it would mean that the Muslims had changed the weight of the coinage, which would, no doubt, mark a deviation from standard Roman coinage.

80 Tillier and Vanthieghem, "Recording debt", 149-53. 
power at its disposal - and there is, in any case, no numismatic evidence for such an attempt before the reign of 'Abd al-Malik. ${ }^{81}$ Moreover, one assumes that an attempt at the withdrawal of the old coinage for reminting would have involved private individuals and government, whilst the parties to the transactions in our papyrus are apparently all private individuals. The Sufyanids seem to have, at least for the time being, contented themselves with issuing a new coinage, and thus the only possible explanation for the recourse of the authorities who oversaw the debt acknowledged in our fragment to the stipulation that the new currency should be used for repayment is that they wanted to enforce the circulation of the new dinar, rather than to remove the previous coinage from circulation. This enforcement was no doubt attempted because of the opposition to the initiative, as reported in the Maronite Chronicle and alluded to by Anastasius Sinaita and al-Maqrīzī. Enforcing the use of an unpopular new coinage for business purposes is not unheard of in the pre-modern world: the Roman emperor Diocletian's (r. 284-305 CE) reform and subsequent revaluation of the coinage, which was likewise met with popular disapproval, had to be shored up by an imperial decree - Diocletian's famed "currency edict" - promulgating new, fixed exchange rates between various denominations and requiring for all debts to be recorded according to the new valuations after 1 September $301 \mathrm{CE}^{82}$

Nonetheless, the equation of the opposition presumed in our papyrus sheet with the one reported in the literary sources would not be self-evident if we took into account Cécile Morrisson and Tony Goodwin's argument that the reason for the failure of $\mathrm{Mu}$ 'awwiya's new coinage to gain currency was that, because of the erasure of the cross, the populace considered the new emissions to be "forgeries", and not for religious reasons. ${ }^{83}$ This contention finds a seeming vindication in Anastasius's assertion, quoted above, that if the Jews, who obviously had no religious attachment to the cross, "see gold without the cross", would "curse it and turn away". If this is true, there is no reason to assume that the papyrological evidence produced here necessarily has the same initiative as that mentioned by the Maronite chronicler and Anastasius as its backdrop, for, by the same token, any change in the iconography of the currency could be construed as a sign of "forgery"; moreover, it is only active resistance on the part of the populace that requires enforcement on the part of the government - if it is only "suspicion", then the government somehow has to procure the people's confidence in the new currency. But it must be noted that, first, Anastasius is plainly contorting the facts here: what in reality happened was that, as he hastens to add, Jews would "eagerly receive" the cross-

81 Hoard evidence from Syria-Palestine attests to the wide - and, presumably, unopposed circulation of Byzantine gold in this period; Metcalf, "Three seventh-century hoards"; Heidemann, "Merger", 95-7.

82 For Diocletian's reforms and edicts, now consult Gilles Bransbourg, "Inflation and monetary reforms in the fourth century: Diocletian's twin edicts of AD 301", in Kevin Butcher (ed.), Debasement: Manipulation of Coin Standards in Pre-Modern Monetary Systems (Oxford: Oxbow, 2020), 165-94.

83 Morrisson, "Trésor byzantin", 63 ("jugée de moindre valeur"); Stephen Album and Tony Goodwin, Sylloge of Islamic Coins in the Ashmolean, vol. i: The Pre-Reform Coinage of the Early Islamic Period (Oxford: Ashmolean Museum, 2002), 91, n. 57 ("forgeries"). 
bearing solidus; the further claim that they would not receive a gold coin because of the absence of the cross is an extrapolation with a polemical intent in mind, a misrepresentation not atypical of apologetic literature. Anastasius's assertion is not a matter-of-fact report on the goings-on in the marketplace, but a demonstration of the power and indelibility of the cross, and so it is only natural for his Jews to be unable to resist its "supernatural" allure. Second, Morrisson and Goodwin's contention is not grounded in the economic realities of pre-modern life either, inasmuch as what mattered the most in the ancient marketplace was the value of the metal used in the coin - rather than its imagery, or, for that matter, "official" status. ${ }^{84}$ One should also take note of the fact that both Anastasius and the Maronite chronicler thought that the effacement of the cross from the coinage was undertaken by someone who occupied a place in state hierarchy - whatever the case may actually have been. Given that, being solitaries in faraway monasteries, they are unlikely to have had privileged access to government correspondence, their claim that the new coinage was a government issue must reflect a popular contemporary view, meaning that the wider (urban) populace also considered these emissions to have been sanctioned by the government, rather than being forgeries, and hence the new coinage would have hardly looked "suspicious" to them. We are thus left with two possible explanations for the alleged failure of the undertaking: the first is to read our sources at face value and take it to be for religious reasons - an explanation that does not sit comfortably with numismatists, who are wont to think in economic terms. The second is to assume that the initiative continued until the end of Mu'āwiya's reign, but was abandoned at some point after his death due to the exigencies of the Second Civil War, and the circulating stock of this coinage would have later been heavily reminted and restruck by 'Abd al-Malik. But all of this is too conjectural and there is no shred of hard evidence to support it. ${ }^{85}$

The nature of the evidence hitherto presented is, inevitably, speculative, but one can make a case for the identification of these "dinars of the believers" with the "crossless" dinars which the author of the Maronite Chronicle and Anastasius mention, and of which we have extant specimens: the so-called dechristianized imperial-image issues which have had the crosses on their obverse removed (and the cross-on-steps on the reverse transformed to a T-shaped object-on-steps ${ }^{86}$ ) - assigned by Morrisson and Foss to $\mathrm{Mu}$ 'āwiya.

84 Note Theophanes's words produced above: "as the gold was paid by weight, the Romans did not suffer any loss from the fact that the Arabs were minting new coin" (Mango and Scott, Chronicle of Theophanes, 510).

85 The weight standard of the Byzantine solidus was around 4.37 grammes at this time and that of our issues ( $\sim 4.35$ grammes; see Table 1$)$ does not seem to diverge significantly from this figure, and hence the failure of the new coinage cannot be blamed on market dynamics; see Gabriela Bijovsky, "A hoard of Byzantine solidi from Bet She'an in the Umayyad period", Revue numismatique 2002, 158, 161-227, at 178, for the average weight of the Byzantine gold circulating in seventh-century Syria. The actual weight standard to which the Byzantine solidus was struck is not known and estimates are based on average weights; see Morrisson, "Byzantine money", 920, for discussion and estimates.

86 The reverse of the solidi of Phocas, however, had another imperial figure on it holding a cross, which has been transformed into a staff on its imitations. 
As to Miles's observation that these issues, with a T-shaped object replacing the cross on their reverse, exhibit a striking similarity in terms of style (crosses removed, but no Islamic legends, in Arabic or otherwise, introduced) with the first Islamic gold emissions of the mint of North Africa in Carthage, it must be pointed out that the development of the post-conquest coinage of Carthage followed an entirely independent course during its first two decades or so, with the region being brought into complete monetary union with the rest of the empire only in 97-100 $\mathrm{AH}$, a full two decades after the introduction of 'Abd al-Malik's trademark aniconic coins in the central and eastern dominions of the empire. ${ }^{87}$ Generally, Muslims seem never to have replaced the coinage of the newly conquered regions with their own overnight, but would introduce piecemeal innovations into the local coinage, such as embroidering its margins with Islamic legends and gradually removing the un-Islamic elements, as is evident from the monetary independence of North Africa, ${ }^{88}$ Tabaristān, ${ }^{89}$ and Bukhāra ${ }^{90}$ in the immediate wake of their conquest - a fact lost on, if not deliberately ignored by, the exponents of fanciful theories of the origins of Islam who base their outlandish ideas on the absence of decidedly Islamic legends, as well as the presence of Christian and Zoroastrian imagery, on the Arab-Byzantine and Arab-Sasanian coinage of early Muslims. ${ }^{91}$

\section{The date and extent of the initiative}

A preponderance of the evidence suggests that there was an attempt to introduce gold coinage under $\mathrm{Mu}$ 'âwiya. What remains to be determined is the date and extent of his reforms, and their potential implications, if any, for our understanding of the nature of his regime. Our papyrus's date of $57 \mathrm{AH} / 676-677 \mathrm{CE}$ and the fact that papyri from the 40s and earlier 50s AH do not make any mention of such reform dinars points to a date in the later $50 \mathrm{~s} \mathrm{AH} / 670 \mathrm{~s} \mathrm{CE}$ for Mu'āwiya's undertaking, a date that neatly dovetails with the pattern we have for the eastern half of the empire, as major developments in the coinage of the east did not get

87 Trent Jonson, "The earliest dated Islamic solidi of North Africa", in Tony Goodwin (ed.), Arab-Byzantine Coins and History: Papers Presented at the 13th Seventh Century Syrian Numismatic Round Table, Held at Corpus Christi College Oxford on 11th and 12th September 2011 (London: n.p., 2012), 157-68, at 157. Metcalf, "Three seventh-century hoards", 97-101, makes some pertinent observations vis-à-vis Miles's continuity argument.

88 Trent Jonson, "A numismatic history of the early Islamic precious metal coinage of North Africa and the Iberian Peninsula" (unpublished $\mathrm{PhD}$ dissertation, University of Oxford, 2014).

89 Hodge Mehdi Malek, The Dābūyid Ispahbads and Early 'Abbāsid Governors of Tabaristān [sic]: History and Numismatics (London: Royal Numismatic Society, 2004).

90 Luke Treadwell, "The monetary history of the bukharkhuda dirham ("black dirham") in Samanid Transoxania (204-395/819-1005)", in Coinage and History in the Seventh Century Near East: Papers from the Seventh Century Syrian Numismatic Round Table (London: Oriental Numismatic Society, 2007), 25-40.

91 A review of some of these writings (I feel hesitant to call them "studies") can be found in Jonathan E. Brockopp, "Interpreting material evidence: religion at the "origins of Islam", History of Religions 55, 2015, 121-47, at 130-33. Cf. ibid., 129, for an argument similar to the one presented above. 
underway until the 50s AH/670s CE either, when Mu'āwiya's viceroy of the east, his adopted brother Ziyād ibn Abī Sufyān, started a harmonization project in the coinage of most of the vast region under his control. This dating also comports well with hoard evidence, which suggests a terminus ante quem of the early $60 \mathrm{~s}$ $\mathrm{AH} / 680 \mathrm{~s} \mathrm{CE}$ for the introduction of these coins: one of Miles's specimens comes from a hoard of Byzantine coins found at Daphne (modern Harbiye near Antioch/Antakya, Turkey), the latest of which were two issues of Constantine IV (r. 668-685 CE) depicting him alongside his brothers and co-emperors Heraclius and Tiberius, ${ }^{92}$ who were mutilated and deposed in $681 \mathrm{CE} .{ }^{93}$ The hoard thus appears to have been buried at some point between 668 and 681 $\mathrm{CE}$ or, at the latest, shortly after $681 \mathrm{CE}$, which firmly places the likely date of the minting of our crossless issue in the Sufyanid period (41-64 AH/661-684 CE). ${ }^{94}$

The Maronite Chronicle, nonetheless, appears to put the initiative at the beginning of Mu'âwiya's reign, which it dates to the year AG 971 (39-40 AH), a dating that has even found favour with some numismatists, ${ }^{95}$ and led some historians to conclude that these gold coins must have been commemorative issues minted on the occasion of Mu'âwiya's accession. ${ }^{96}$ But it is hard to believe that $\mathrm{Mu}$ āwiya was able to embark on any large-scale undertaking immediately after the close of the civil war, especially in a region where there was no tradition of gold minting for well over a century.

What is more, a closer examination of the passage reveals that the chronicler is, in fact, not making such an assertion, but is offering a brief account of $\mathrm{Mu}$ 'āwiya's whole reign. After giving a somewhat detailed account of Mu'àwiya's triumph in the First Civil War (36-41 AH/656-661 CE) and his accession to power, the chronicler observes that:

in July of the same year the emirs and many Arabs gathered and proffered their right hand to Mu'āwiya. Then an order went out that he should be proclaimed king in all the villages and cities of his dominion and that they should make acclamations and invocations to him. He also minted gold and silver, but it was not accepted, because it had no cross on it

92 Metcalf, "Three seventh-century hoards", 95-6; Hoyland, Seeing Islam, 138, n. 73.

93 E.W. Brooks, "The brothers of the emperor Constantine IV", The English Historical Review 30, 1915, 42-51.

94 Miles himself was more circumspect, and argued for a date in "the decade before 691 and probably closer to 690 than to 680" (Miles, "Earliest gold", 229), but later numismatists would venture a date as early as the early $60 \mathrm{~s} \mathrm{AH} / 680 \mathrm{~s} \mathrm{CE}$; Foss, "Syrian coinage", 363; Heidemann, "Evolving representation", 160.

95 See, among others, Morrisson, "Trésor byzantin", 63; Morrisson, "Monnayage omeyyade", 312; Luke Treadwell, "The formation of religious and caliphal identity in the Umayyad period", in Finbarr Barry Flood and Gülru Necipŏglu (eds), A Companion to Islamic Art and Architecture (Hoboken, New Jersey: Wiley, 2017), 89-108, at 95-6; Treadwell, Chronology of Pre-Reform Copper Coinage, 5; Treadwell, "'Abd al-Malik's coinage reform", 368; and also Foss, "Mu āwiya's state", 86.

96 James Howard-Johnston, Witnesses to a World Crisis: Historians and Histories of the Middle East in the Seventh Century (Oxford: Oxford University Press, 2010), 178; Marsham, "Architecture of allegiance", 88. 
(țba' dēn āp dahbā w-sèmā w-lā etqabbal mețtūl d-layt hwā bāh șlībāa). Furthermore, Mu'āwiya did not wear a crown like other kings in the world. He placed his throne in Damascus and refused to go to Muhammad's throne. ${ }^{97}$

As can be seen, the chronicler is giving some general information about the new caliph, his tastes, manners, and deeds, here, rather than a list of events that occurred during a particular year of his reign. This appears to be a standalone account of Mu'âwiya's reign taken from a source similar to the so-called "brief Syriac chronicles" 98 and inserted into our chronicle, an assumption that also explains why we have three, somewhat irreconcilable accounts of the pledge of allegiance (bay' $a$ ) to the Umayyad dynast in the text: they are separate narratives coming from different sources that have been put together by the chronicler-compiler, with little attempt at harmonization.

The narrative of the First Civil War in the Maronite Chronicle is lacunose and the extant part begins with an account of Mu'āwiya going to al-Hīra, near Kufa, in Iraq, and receiving the allegiance of the people there after the assassination of the caliph 'Alī ibn Abī Tâalib (r. 36-40 AH/656-660 CE). ${ }^{99}$ This report is placed before the entry for AG 971 (39-40 AH), whereas Mu'āwiya only took control of Iraq in $41 \mathrm{AH}$. There then follows a second pledge of allegiance in AG 971 in Jerusalem, with lots of pomp and ceremony, followed by the above-quoted notice, which is the third homage to Mu'awwiya. ${ }^{100}$ While some scholars have granted leave to the idea of a third oath of allegiance, it is unlikely that $\mathrm{Mu}$ 'awiya received the pledge of allegiance on more than two occasions, the first in Syria and the second in Iraq, ${ }^{101}$ inasmuch as the bay $a$ was an irrevocable, reciprocal contract between two parties, which would only expire at the death of either or both of them, and whose breach was punishable by death. ${ }^{102}$ Once the Syrians and Iraqis had both sworn their loyalties to $\mathrm{Mu}$ 'âwiya, there would be no point in taking another pledge from both groups as a whole without the first having been revoked. The best way to make sense of these apparent contradictions, then, is to assume that the chronicler has made use of a disparate array of sources.

This suggestion finds corroboration in the fact that Muslim sources do not show awareness of a third pledge of allegiance to $\mathrm{Mu}$ 'awiya after the death of

97 Text: E.W. Brooks, Chronica Minora II= Corpus scriptorum christianorum orientalium: Scriptores syri, series 3, vol. 4 (Paris: Charles Poussielgue, 1904), 71; translation: Palmer, West-Syrian Chronicles, 32 (I am grateful to Salam Rassi for helping me with the Syriac).

98 A sobriquet bestowed on them by Andrew Palmer; see most recently his "Les chroniques brèves Syriaques", in Muriel Debié (ed.), L'historiographie syriaque (Paris: Geuthner, 2009), 57-87.

99 Palmer, West-Syrian Chronicles, 29-30.

100 Palmer, West-Syrian Chronicles, 31.

101 Pace Marsham, "Architecture of allegiance", 90-97, whose treatment of the episode could hardly have been more cautious, but who seems receptive to the possibility of a third bay'a.

102 Ella Landau-Tasseron, The Religious Foundations of Political Allegiance: A Study of bay'a in Pre-Modern Islam (Washington: Hudson Institute Research Monographs on the Muslim World, series 2, paper no. 4, May 2010), passim, especially 26-7. 
'Alī either: he once received the allegiance of the people (of Syria, presumably) in Jerusalem, and once in Iraq after the surrender of 'Alī's son and successor al-Hasan; ${ }^{103}$ al-Tabarı̂'s unique statement that, after al-Hasan's surrender, "the people as a whole pledged allegiance to Mu'āwiya and [that year] became

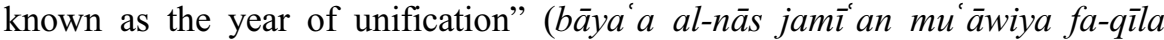
' $\bar{a} m$ al-jam $\bar{a} ' a)^{104}$ is to be understood as him having been recognized as caliph all over the empire with the capitulation of Iraq, rather than as a reference to a third oath of allegiance. ${ }^{105}$ In any event, the Maronite Chronicle's second and third accounts on the accession of Mu'āwiya look suspiciously like each other, a fact which led Julius Wellhausen to conclude that they derive from, "two independent narratives of the same event". ${ }^{106}$ If this stratification of the chronicle is correct, then the above-quoted notice on the accession of Mu'āwiya and his minting of crossless gold and silver must be considered an independent, brief account of the entire period of Mu'āwiya's caliphate emanating from an older, now-lost source, and ought not to be construed as testimony for a precocious attempt at monetary reform on the part of the caliph. The papyrological and literary evidence, then, do not appear to be in discord.

It thus transpires that Mu'àwiya concurrently initiated a process of monetary expansion in both of the two main currency zones of his empire, Syria and Iran-Iraq, during the latter years of his reign. ${ }^{107}$ But there is more to this: our

103 He had also received the allegiance of the Syrian army (ahl al-sham $)$ as caliph after the failure of the arbitration following the battle of Șiffin, but before the death of "Alī in 40 $\mathrm{AH} / 660 \mathrm{CE}$; Marsham, "Architecture of allegiance", 92 and n. 15 thereto; to this evidence the following three pieces should be added: al-Maqrīzī, al-Dhahab al-masbūk fi dhikr man hajja min al-khulafä' wa-l-mulük (Caliphate and Kingship in a Fifteenth-Century Literary History of Muslim Leadership and Pilgrimage), ed. Jo van Steenbergen (Leiden: Brill, 2016), 224: "the Syrian army alone pledged allegiance to him as caliph in 38 or 39" (wa-bāya' a lahu ahl al-shām khāssatan bi-l-khilāfa sanat thamān aw tis wa-thalāthīn); Khalīfa ibn Khayyāț, Ta' rīkh, ed. Akram Diyā' al-'Umarī (Riyadh: Dār al-tayyiba, 1405/1985), 192 (I owe this reference to Peter Webb): "the Syrian army pledged allegiance to Mu'āwiya as caliph in Dhū al-qa da 37" (wa-bāya'a ahl al-shām li-mu'āwiya bi-l-khilāfa fì dhì al-qa'da sanat sab' wa-thalāthīn); and Muhammad ibn Yazīd, Ta' rīkh al-khulafäa', ed. Muḥammad Muṭī al-Ḥāfiz, "Ta' rīkh al-khulafā' li-abī 'abd allāh muhammad ibn yazīd riwāyat abī bakr al-sadūs̄̄ 'anhu", Majallat majma' al-lugha al-'arabiyya bi-dimashq 54, 1979, 395-454, at 419: "the Syrian army had pledged its allegiance to Mu'āwiya after the two arbiters recessed in Dhū al-ḥijja 37" (wa-qad kāna ahl al-shām bāya' ū mu'āwiya hìna tafarraqa l-hakamān sanat sab' wa-thalāthīn fì dhì al-hijja). See further Shaddel, Sufyanids, on this.

104 al-Ṭabarī, Ta’ rīkh al-rusul wa-l-mulūk, ed. Michael Jan de Goeje (Leiden: Brill, 1881-83), vol. 2, 199; cited by Marsham, "Architecture of allegiance", 93.

105 Consult Marsham, "Architecture of allegiance", 90-97, for further discussion of the source material and its problems.

106 Julius Wellhausen, The Arab Kingdom and Its Fall, tr. Margaret Graham Weir (Calcutta: University of Calcutta Press, 1927), 101; followed by Andrew Marsham, Rituals of Islamic Monarchy: Accession and Succession in the First Muslim Empire (Edinburgh: Edinburgh University Press, 2009), 88.

107 Metcalf, "Three seventh-century hoards", 97-101; followed by Bates, "History, geography and numismatics", 239, n. 10; and Marcus Phillips, "Coinage and the early Arab state", in Oddy et al., Coinage and History in the Seventh Century Near East $4,53-71$, at $66-8$, has argued that these issues were not "official", "caliphal" emissions, 
papyrus has its provenance in Egypt, while the hypothesized introduction of gold is supposed to have taken place in Syria. This means that the expansionary drive must have taken place on a much grander scale than hitherto imagined, encompassing nearly the entirety of $\mathrm{Mu}$ 'âwiya's vast realm, or else, with a meagre amount of the new currency available in Egypt, any attempt to enforce its use there would have been meaningless. The literary evidence lends some credence to the idea of a large-scale undertaking, inasmuch as it comes from several different places - to wit, Syria, Sinai, and Egypt.

This conclusion is very puzzling given that the number of extant specimens of dechristianized gold issues barely runs to over a dozen. ${ }^{108}$ Foss has argued that this is precisely because of the fact that the reform was a failure. ${ }^{109}$ In other terms, the opposition to the undertaking must have been so strong that the authorities desisted soon afterwards and stopped the issuance of the new gold. In the early Islamic empire, the army was both the largest consumer and circulator of coined money, ${ }^{110}$ with most mintages going directly from the mints to the army's coffers, and thence spread to the wider population. There is also evidence for "itinerant mints" which were based not at a specific locality, but moved with large units to feed the army's insatiable appetite for cash. ${ }^{111}$ In the light of this, and if there is any substance to al-Maqrīìi's report on the opposition to the new issues within the ranks of the army, it is even possible that large quantities of these new dinars were almost immediately withdrawn and melted down, with the gold being put to other use. This supposition would also account for the fact that we have not found any other attestations of the phrase danānir qad़े al-mu'minin in the papyri, as the enforcement period would have been equally brief.

But can we be sure of this? Is it not possible that P. Vindob. A 1119 is referring to something totally different, something we have no other evidence for; that the initiative was limited to Syria; and that, as some have argued, the

but were produced by local authorities around the $670 \mathrm{~s}$ CE. True, the extent of the involvement of the caliph in this venture is open to debate, but the pattern of developments under $\mathrm{Mu}$ 'âwiya, in both the east and the west, makes it hard to resist the conclusion that the central government had at least some modicum of involvement with it; cf. further below.

108 See Table 1.

109 Foss, "A Syrian coinage", 363.

110 Hugh Kennedy, "Military pay and the economy of the early Islamic state", Historical Research 75, 2002, 155-69, especially 159-60; Hugh Kennedy, Armies of the Caliphs: Military and Society in the Early Islamic State (London: Routledge, 2001), 56-95, particularly $67-71$.

111 The best and most sophisticated analysis of such a phenomenon is to be found in Jonson, "Numismatic history" 84-7, 343-8, 390-400, et passim. For another example, consult Sears, "Monetary history", 168-72. In a fascinating study, Michael Bates argues, based on the sequence of the issues of the mints of the super-province of the "North" and the dates for the campaigns undertaken by the governor of the region as given in literary sources, that there was only a single mint operative in the entirety of the province at each time, but that it travelled with the governor and their army, and always assumed the name of the city in which it was operating; see Michael L. Bates, "The dirham mint of the northern provinces of the Umayyad caliphate", Armenian Numismatic Journal 15, 1989, 89-111. 
harmonization of the coinage we observe in the east was a personal undertaking of the two powerful viceroys of the east, Ziyād and his son, 'Ubayd Allāh? If the reform was really attempted on an empire-wide scale, the number of workshops that produced the new issues and/or the dies used for striking them, would have been quite substantial, in which case, by the dictation of the laws of probability, the proportion of pairs of dies used to strike the extant specimens to their number would be very high, something close to 1 .

Since the publication of Miles's classification, no new types of dechristianized imitative gold dinars have come to light, and accordingly his classification of these issues still remains valid: they are of three types, each of which imitates a particular series of the Byzantine solidus: imitations of the solidus of Phocas (r. 602-610 CE); imitations of the solidus of Heraclius (r. 610-641 CE) and Heraclius Constantine (r. 613-641 CE); and those of the solidus of Heraclius, Heraclius Constantine, and Heraclonas (r. 638-641 CE). One could also classify each of these three types into further subtypes on the basis of the additional letters on their reverses, but I shall refrain from so doing for the sake of simplicity. I have had access to nineteen specimens for examination. Of these, two belong to the first type, each of which has been struck with a unique obverse and a unique reverse die. Of the second type, I know of nine specimens, no two of which share either an obverse or a reverse die. And of the third type, eight specimens have been available to me, which have been struck by seven different obverse dies and six different reverse dies. In total, 19 obverse dies and 18 reverse dies have been used in striking the nineteen specimens.

The combined number of obverse and reverse dies used for striking a given number of coins could be anything between 2 and twice the number of coins struck, allowing for a die to specimen ratio of between 0 and 2; in this case, the die to specimen ratio is very close to the maximum possible of 2 (or $37 / 19$ $=1.947$, to be more precise). Given that two dies would have more than sufficed for striking 19 pieces, and assuming that these 19 specimens constitute a random statistical sample, the large number of dies (as well as the great diversity of types and subtypes) indicates that the initial output of this coinage must have been very large, but for some reason only a small number are now extant. This finding comports with the notion of a large-scale, ultimately short-lived initiative. It is important to note that, even in absolute terms, 19 obverse and 18 reverse dies are huge numbers for a gold coinage: Roman historian Richard Duncan-Jones has estimated that the total number of pairs of dies used for minting gold during the 20-year reign of the Roman emperor Hadrian (117-138 CE), when the Roman empire was at the apex of its extent, was something between 500-1000, and that, annually, around 25-50 pairs of dies were put to use. ${ }^{112}$ This estimate means that the number 18.5 pairs for a gold coinage that is thought to have been withdrawn very quickly is quite considerable, as would have been the number of the workshops that produced it - further evidence in support of the substantial scale of the undertaking. ${ }^{113}$

112 Richard Duncan-Jones, Money and Government in the Roman Empire (Cambridge: Cambridge University Press, 1994), 159, 162. Cf. also the die numbers for 'Abd al-Malik's reform gold in Treadwell, "A Abd al-Malik's coinage reforms", 363-4.

113 The number of mints, however, need not necessarily have been more than one, as was the case in Byzantium and, presumably, during the later Umayyad period. 
Table 1. Extant specimens of Mu'āwiya's dechristianized solidi

\begin{tabular}{|c|c|c|c|}
\hline & Prototype & $\begin{array}{l}\text { Weight } \\
\text { (grammes) }\end{array}$ & Notes \\
\hline 1 & Regular solidus of Phocas & 4.33 & Miles, "Earliest gold", plate 45, no. 2, and p. $207^{114}$ \\
\hline 2 & 11 & 4.45 & Phillips, "Coinage and early Arab state", 66, fig. 15a \\
\hline 3 & $\begin{array}{l}\text { Regular solidus of Heraclius and } \\
\text { Heraclius Constantine }\end{array}$ & 4.36 & Miles, "Earliest gold", plate 45, no. 4, and pp. 207-8 \\
\hline 4 & $" 1$ & 4.44 & $\begin{array}{l}\text { Miles, 'Earliest gold', plate 45, no. 6, and p. } 208 \text { (American Numismatic Society, } \\
\text { holding no. 1983.122.1) }\end{array}$ \\
\hline 5 & "I & 4.42 & Heidemann, "Evolving representation", 160, fig. 7 \\
\hline 6 & " & 4.20 & Phillips, "Coinage and early Arab state", 66, fig. 15b \\
\hline 7 & " & 4.33 & $\begin{array}{l}\text { Marcus Phillips, "From ancient to medieval: the significance of fixed axes dies", } \\
\text { in Tony Goodwin (ed.), Coinage and History in the Seventh Century Near East } \\
\text { 6: Proceedings of the } 16^{\text {th }} \text { Seventh Century Syrian Numismatic Round } \\
\text { Table Held at the Hive, Worcester, on } 6^{\text {th }} \text { and } 7^{\text {th }} \text { April } 2019 \text { (London: } \\
\text { Archetype, 2020), 203-21, at } 210\end{array}$ \\
\hline 8 & $" 1$ & 4.27 & Figure 1 (Stephen Album Rare Coins, auction 23, September 2015, lot 68) \\
\hline 9 & "I & 4.37 & Figure 2 (Numismatica Genevensis, auction 12, November 2019, lot 158) \\
\hline 10 & "I & - & Figure 3 (Spink, 1989, lot 12) \\
\hline 11 & " & - & Figure 4 (Spink, March 1999, lot 5) \\
\hline 12 & $\begin{array}{l}\text { Regular solidus of Heraclius, Heraclius } \\
\text { Constantine, and Heraclonas }\end{array}$ & 4.46 & Miles, 'Earliest gold', plate 45, no. 8, and p. 209 \\
\hline
\end{tabular}

114 Foss, "Syrian Coinage", 362, n. 38, contends, on the authority of Marcus Phillips, that this issue is a forgery. However, as Mr Phillips indicates to me (personal communication), he has no recollection of casting doubt on the authenticity of this specimen. The specimen that he, Susan Tyler-Smith, Tony Goodwin, and Peter Donald examined and dismissed as a fake (but not "forgery") was a genuine, non-imitative issue of Phocas which had had, as Tyler-Smith discovered, the horizontal bar of its cross removed, likely in modern times. 
Table 1. Continued

\begin{tabular}{|c|c|c|c|}
\hline & Prototype & $\begin{array}{l}\text { Weight } \\
\text { (grammes) }\end{array}$ & Notes \\
\hline & " & 4.19 & $\begin{array}{l}\text { Bates, "History, geography and numismatics", plate } 31 \text {, no. } 1 \text {; Album and } \\
\text { Goodwin, Sylloge, plate 41, no. 606; Heidemann, "Evolving representation", } \\
\text { 171, fig. } 17 \\
\text { Shares its reverse die with no. } 18\end{array}$ \\
\hline 14 & $" 1$ & 4.23 & Phillips, "Coinage and early Arab state", 66, fig. 15c \\
\hline 15 & $" 1$ & 4.43 & Phillips, "Coinage and early Arab state", 66, fig. 15d \\
\hline 16 & $" 1$ & - & Bates, "History, geography and numismatics", plate 31 , no. 2 \\
\hline 17 & $" 1$ & 4.42 & Phillips, "From ancient to medieval", 210 \\
\hline 18 & $" 1$ & 4.34 & $\begin{array}{l}\text { Figure } 5 \text { (New York Sale, auction 45, January 2019, lot 314) } \\
\text { Shares its reverse die with no. } 13\end{array}$ \\
\hline 19 & $" 1$ & 4.25 & Figure 6 (TimeLine Auctions, coins auction, 19 June 2013, lot 0273) \\
\hline
\end{tabular}




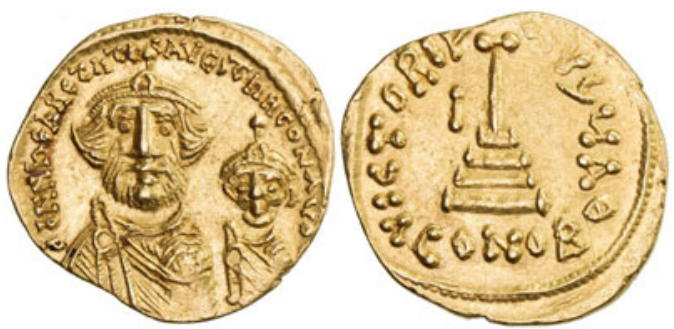

Figure 1. Stephen Album Rare Coins, auction 23, September 2015, lot 68

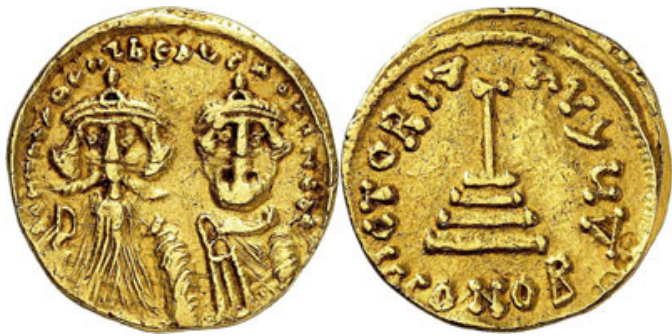

Figure 2. Numismatica Genevensis, auction 12, November 2019, lot 158

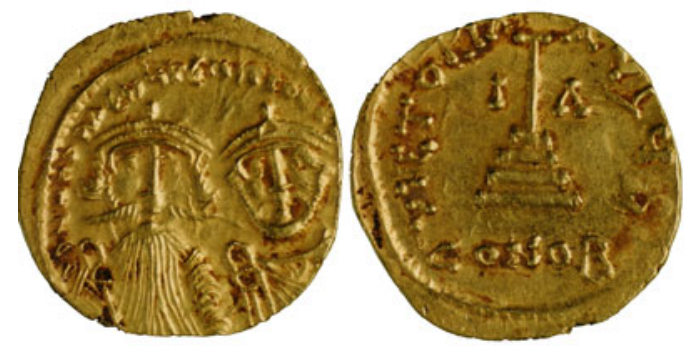

Figure 3. Spink, 1989, lot 12
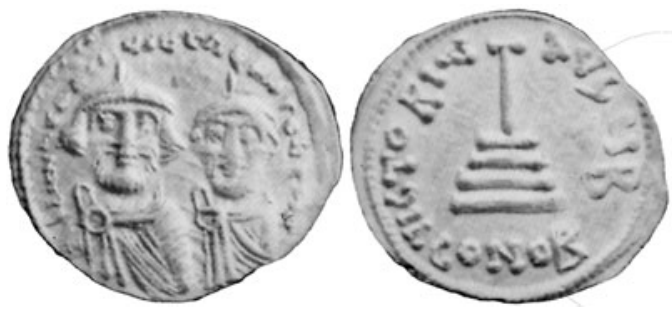

Figure 4. Spink, March 1999, lot 5 

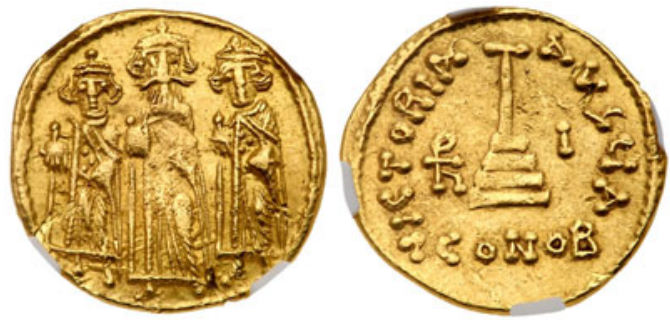

Figure 5. New York Sale, auction 45, January 2019, lot 314

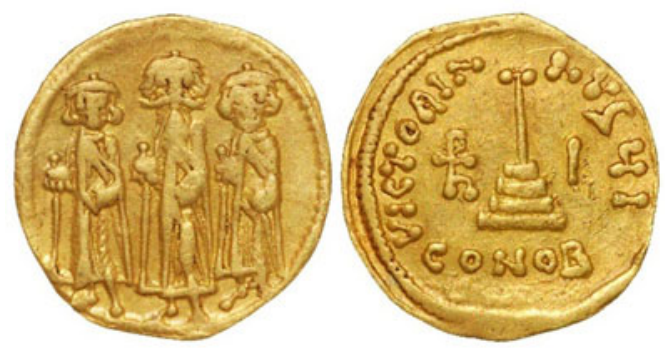

Figure 6. TimeLine Auctions, coins auction, 19 June 2013, lot 0273

To recapitulate briefly, we have literary evidence - in Arabic, Greek, and Syriac - for the introduction of a gold denomination peculiar to early Muslims under Mu'āwiya; this literary evidence finds some corroboration, albeit circumstantial, in an Egyptian papyrus dated to $57 \mathrm{AH}$; and gold imitations of the Byzantine solidus are also known that fit the descriptions in the textual sources and could accordingly be attributed to Mu āwiya. A re-examination of our literary sources shows that this initiative is not necessarily to be dated to the beginning of $\mathrm{Mu}$ 'àwiya's reign, and the evidence of the papyrus fragment points to a date in the later $50 \mathrm{~s} \mathrm{AH}$, around the time of increased minting activity in the east. A die-study of the extant specimens shows that they were struck using a large number of dies, a sign that the initiative was a large-scale one. On the other hand, the fact that the number of extant specimens is limited constitutes evidence for the assertion of our textual sources that the initiative ultimately proved a failure. ${ }^{115}$

\section{Mu'āwiya's state}

Much ink has been spilt during the past three decades on the nature of the nascent Muslim state, the extent to which the centre (first at Medina, then in Syria) could impose its will on the outlying regions, and if we can speak of a "central

115 David Woods, "Mu'āwiya, Constans II and coins without crosses", Israel Numismatic Research 10, 2015, 169-81, has recently argued that the crossless coins said by the Maronite chronicler to have been issued by $\mathrm{Mu}$ 'āwiya are not to be identified with the crossless issues discussed here, but with a particular series of gold and silver issues of Constans II, which as it happens have crosses on both the obverse and the reverse. 
government" at this early stage. I have given a summary of these debates, along with some musings of my own, elsewhere, ${ }^{116}$ and hence the following discussion shall be confined to the interrogation, in broad strokes, of the extent to which the central government was involved in these early attempts at monetary reform.

$\mathrm{Mu}$ 'âwiya introduced his new gold coinage in response to a slump in the gold supply of the region in the second half of the seventh century. Some scholars have argued that this slump, evidenced by the predominance of Heraclian solidi in five seventh-century gold hoards from Syria-Palestine, might be an indication of a sharp decline in the flow of Byzantine gold into Syria immediately after the conquest of the region by Muslims. ${ }^{17}$ This argument, however, does not take into account two more factors that might also have been at play here: the first is the "horseshoe effect", or the fact that the best represented issues in a so-called saving hoard come from the middle of the time-interval for which we have representation in the hoard, resulting in a horseshoe curve on a specimen-time diagram; ${ }^{118}$ this means that in the case of the Daphne hoard, for instance, it is only natural for Heraclian solidi to be better represented at the expense of previous and later reigns, since the hoard contains issues from the reign of the emperor Maurice (582-602 CE) until that of Constantine IV (668-685 CE), and the period of Heraclius's later reign (r. 610-641 CE), which is the best represented, falls exactly in the middle of this time interval. In other terms, the actual slump might have been less steep than the relative number of issues in the hoards would suggest. The second, and more important, factor is that the overrepresentation of the gold coins of Heraclius in these hoards, at the expense of those of his successors, may in fact be a sign of decreased minting activity under his successors, a suggestion that is corroborated by the evidence of Byzantine hoards found in the territories of the Byzantine empire itself: a marked decline is observable in gold-minting activity in the Byzantine empire during the latter half of the seventh century, a pattern that becomes more acute at the end of Constans II's reign (641-668 CE), and is a telltale sign of the shrinkage of the Byzantine economy in this period. ${ }^{119}$ But, whether a decrease in gold-minting activity or a decline in its flow from Byzantium into Syria, or a combination thereof, it is against this background that Mu'āwiya embarked on an expansionist monetary policy in Syria and Egypt, which nicely fits into the pattern of monetary expansion and reform that we observe in the east at about the same time: in the year $53 \mathrm{AH} / 673 \mathrm{CE}$, during the governorship of Ziyād ibn Abī Sufyān (c. 47-53 AH/667-673 CE), ${ }^{120}$ a new mint opened at the

116 Shaddel, Sufyanids.

117 Heidemann, "Merger", 96; followed by Foss, "Syrian coinage", 357; and Treadwell, "Abd al-Malik's coinage reforms", 367.

118 As Kris Lockyear notes in his statistical analysis of Roman coin hoards, "immediately after the coinage has been released into the coinage pool there will be small differences between hoards as a result of the irregular distribution - hoards will either have a small number of coins of that date, or will have none and the closing date will not reflect the actual deposition date"; Kris Lockyear, Patterns and process in Roman republican coin hoards, 157-2 BC (Oxford: Archaeopress, 2007), 223.

119 Morrisson, "Byzantine money", 954-7.

120 For an outline of Ziyād's career, his coinage, and the dates of his appointments and death, see Michael L. Bates, "How Ziyād made a name for himself" (forthcoming). 
garrison town of Basra, in southern Iraq. Beginning in $56 \mathrm{AH} / 676 \mathrm{CE}$, under the rule of Ziyād's son, 'Ubayd Allāh (56-64 AH/676-684 CE), the mint of Basra emerged as the most productive in the east: the Basra issues of 'Ubayd Allāh account for almost half of the coinage issued in his name, and are also the most represented in the entire Arab-Sasanian corpus. ${ }^{121}$ Moreover, as Stuart Sears notes, "the uniform use of legends and the simultaneous opening and closing of mints all over Iraq and Iran demonstrate the central government's interest in and authority over minting" in this period. ${ }^{122}$ As such, the introduction of a local precious metal denomination in Syria and Egypt must be understood as part of a larger programme of monetary expansion.

It must be borne in mind that a real bimetallic monetary system was only introduced under 'Abd al-Malik, who minted both gold and silver in Syria (in addition to copper). ${ }^{123} \mathrm{Mu}$ 'āwiya's initiative was in fact an attempt to introduce a local gold denomination in Syria and Egypt alone, while in Iran the silver standard (with copper playing the role of small change) remained dominant for the time being - in other words, the empire was still divided into two distinct currency zones.

This surge in minting output throughout the empire is a sign of the increased monetization of the economy in the late Sufyanid period, a development certainly called for by the state's extravagant building programmes and the attendant rise in expenditure, for which we now have ample evidence. In the words of Shaun O'Sullivan:

the fact that the church of St Sergius kept many fiscal papers during the period 674-690 is circumstantial evidence that an exacting fiscal climate existed at Nessana [in the southern Negev, Israel]. This suggests that the Umayyad administration not only produced much administrative documentation but also required tax-payers to present and reproduce documentation proving that they had fulfilled their fiscal dues. ${ }^{124}$

Tillier and Vanthieghem's identification of a certain number of Egyptian papyri as state registers ${ }^{125}$ attests to the inauguration of a rudimentary form of chancery archives in early Sufyanid Egypt, and extends the ambit of O'Sullivan's exacting fiscal climate to this province as well.

Expanding the supply of money was Mu'āwiya's solution to the problem of funding for this rapidly growing state apparatus, and the maturation of state structures would in turn make monetary reform possible. It is true that the Sufyanid polity was, to quote Chase Robinson, by and large a "laissez-faire patrimonial regime", ${ }^{126}$ and Johns's observation that Mu'āwiya's name occurs only once in the extant documents from Egypt dating to his reign ${ }^{127}$ is no

121 Album and Goodwin, Sylloge, 16.

122 Sears, "Monetary history", 377-402 (the quote comes from p. 382).

123 Treadwell, "'Abd al-Malik's coinage reforms".

124 Shaun O'Sullivan, "Fiscal evidence from the Nessana papyri", in Alexander T. Schubert and Petra M. Sijpesteijn (eds), Documents and the History of the Early Islamic World (Leiden: Brill, 2015), 50-74, at 51.

125 Tillier and Vanthieghem, "Recording debt", 149-53.

126 Chase F. Robinson, 'Abd al-Malik (Oxford: Oneworld, 2005), 22-5, 62-6.

127 Johns, “Archaeology”, 418, n. 10. 
less true today than it was in 2003, but evidence for the emergence of a fledgling centrally organized bureaucracy under the Sufyanids has been building up since then. The lack of references to the caliph in the provinces and the isolated nature of the projects, such as the reorganization of the east under Ziyād and his son, should thus be understood as some sort of "division of labour" or delegation of duties. In other words, the Sufyanids were neither themselves micromanagers, nor would their governors deign to meddle in the minute aspects of every enterprise, but they no doubt presided over gargantuan endeavours on an imperial scale, unheard of since the previous century under Justinian and Khusraw I and II. ${ }^{128}$ Otherwise, the caliph was very much present at a local level: monumental inscriptions from Palestine ${ }^{129}$ and the Hijā $\mathrm{z}^{130}$ make mention of projects undertaken at his behest, using extremely consistent formularies; in the east, at the mint of Dārābjird, silver coins were issued in his name, referring to him in Middle Persian as 'myr y wlwyšnyk' n, or "commander of the believers"; 131 and in Egypt, Greek papyri attest to the presence of caliphal agents, referred to as

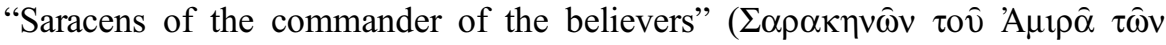
$\mathrm{P} \imath \tau \hat{\omega} v)$, doing his bidding in the Upper Nile valley. ${ }^{132} \mathrm{Mu}$ 'âwiya's regime no doubt lagged far behind 'Abd al-Malik's in terms of complexity, resources, and power, but the Sufyanid "system of delegated rule"133 in many ways foreshadowed the centrally organized Marwanid administration.

128 Judging by the variety in type of Mu'āwiya's gold coinage, the choice of a prototype seems to have been left to local (or even mint/workshop, if there was more than one) authorities, which may be construed as further evidence for the caliph's laissez-faire approach to government.

129 Yizhar Hirschfeld and Giora Solar, "The Roman thermae at Hammat Gader: preliminary report of three seasons of excavation", Israel Exploration Journal, 31, 1981, 197219.

130 George C. Miles, "Early Islamic inscriptions near Țā' if in the Hijāz", JNES, 7, 1948, 236-42; Saad bin Abdulaziz al-Rāshid, "Sadd al-Khanaq: an early Umayyad dam near Medina, Saudi Arabia", Proceedings of the Seminar for Arabian Studies, 38, 2008, 265-76; idem (Sa'd b. 'Abd al-'Azīz al-Rāshid), Dirāsāt fì al-āthār al-islāmiyya al-mubakkira bi-l-madīna al-munawwara (Riyadh: Mu' assat al-ḥazìmī li-l-tijāra wa-l-tawkīlāt, 1421/2000), 32-60.

131 Album and Goodwin, Sylloge, 15.

132 Roger Rémondon, Papyrus grecs d'Apollônos Anô (Cairo: Institut français d'archéologie orientale, 1953), 86-8 (no. 37); cited by Foss, "Mu āwiya's state", 90; for the date of the dossier, see Foss, "Flavius Papas and Upper Egypt", 4-5. Petra M. Sijpesteijn, Shaping a Muslim State: The World of a Mid-Eighth-Century Egyptian Official (Oxford: Oxford University Press, 2013), 63, n. 102, believes them to have been sent, "not from Damascus ... but rather in the caliph's name from Fusțâtet". This is more than plausible, but the pagarch in Upper Egypt would apparently have been sufficiently in awe of the caliph in Damascus for the governor at Fustât to attempt to ensure obedience by invoking his name.

133 A phrase I have borrowed from R. Stephen Humphreys, Mu'awiya ibn Abi Sufyan: From Arabia to Empire (Oxford: Oneworld, 2006), 94. 